JOURNAL OF SECURITY AND SUSTAINABILITY ISSUES

ISSN 2029-7017 print/ISSN 2029-7025 online

2021 Volume 11

https://doi.org/10.47459/jssi.2021.11.40

\title{
MULTIDIMENTIONAL ANALYSIS OF THE DECLINE OF RAIL PASSENGERS IN EUROPEAN COUNTRIES IN 2020 IN TERMS OF ECONOMIC SECURITY
}

\author{
Marek Magniszewski ${ }^{1}$, Bartosz Kozicki ${ }^{2}$ \\ ${ }^{1}$ Rzeszów University of Technology, Poland \\ ${ }^{2}$ Military University of Technology, Poland \\ E-mail:"1magniszewsk@prz.edu.pl; 2bartosz.kozicki@wat.edu.pl
}

Received 11 March 2021; accepted 15 June 2021; published 30 June 2021

\begin{abstract}
The article presents a multidimensional comparative analysis of the drops in the number of passengers transported by rail in 28 European countries on a quarterly basis in 2012-2020 in terms of the impact of the COVID-19 pandemic and economic security. Data collected from Eurostat on the number of passengers transported by rail in 28 European countries were aggregated and further analyzed in order to emphasize the regularities governing them. The research has observed a growing trend on an annual and quarterly basis in the total number of passengers transported by rail in 28 European countries in 2012-2019. Additionally, in the unnamed (quarterly) data, a quarterly seasonality was detected. Since 2020, there have been declines in the number of passengers transported by rail in all of the 28 European countries considered. The declines were subjected to a comparative analysis, adopting various criteria, in order to assess which countries were most affected by the COVID-19 pandemic in terms of rail passenger transport.
\end{abstract}

Keywords: transport; rail transport in Europe; COVID-19; multidimensional data analysis; economic security; European countries

Reference to this paper should be made as follows: Magniszewski, M., Kozicki, B. 2021. Multidimensional analysis of the decline of rail passengers in European countries in 2020 in terms of economic security. Journal of Security and Sustainability Issues, 11, $441-455$. https://doi.org/10.47459/jssi.2021.11.40

JEL Classifications: K19

Additional disciplines: political sciences and administration, law

\section{Introduction}

The study identifies a research problem that focuses on a multivariate comparative analysis of the number of passengers transported by passenger rail in 28 European countries on a quarterly basis between 2012 and 2020 . In addition to the research problem, the main objective of the study is outlined. The main objective of the study is to investigate in which of the considered European countries the decreases in the number of passengers transported due to the COVID-19 pandemic were the highest and in which were the lowest. For the research problem and objective of the paper thus adopted, the main hypothesis was outlined: What $\%$ of the number of transported passengers by rail in 2019 in 28 individual European countries were the decreases caused by the COVID-19 pandemic in 2020? The subject of the study is the number of passengers transported by rail transport in 28 European countries. The research period covers the years 2012-2020.

The study includes a literature analysis of transport issues, including rail passenger transport. Issues concerning COVID-19 infectious disease and multivariate comparative analyses were addressed. A comparative analysis of the number of passengers transported by rail in dynamic terms in the 28 European countries analysed was performed. Data clustering was used within this method (Jurgilewicz et al., 2020). 


\section{Literature analysis}

Many interpretations of the term transportation can be found in the literature (Table 1).

Table 1. Summary of definitions of the term transportation.

\begin{tabular}{|c|l|}
\hline Author & \multicolumn{1}{c|}{ Definition } \\
\hline $\begin{array}{c}\text { E. Gołembska, } \\
\begin{array}{c}\text { Z. Bendyt, } \\
\text { M. Gołembski }\end{array}\end{array}$ & $\begin{array}{l}\text { Transportation is the activity of moving the tangible resources of companies in the supply chain (Golembska, } \\
\text { Bendyt, \& Golembski, 2017, p. 48). }\end{array}$ \\
\hline H. Karbowiak & Transportation is the activities of loading and handling (Karbowiak, 2009, p. 7). \\
\hline $\begin{array}{c}\text { M. Jacyna, } \\
\text { K. Lewczuk }\end{array}$ & Transportation is a production process whose purpose is to traverse space (Jacyna, Lewczuk, 2016, p. 88). \\
\hline M. Stajniak & $\begin{array}{l}\text { Transportation in economic terms is identified with supply chain management activities and the paid provision of } \\
\text { services in terms of: movement, storage, packaging and others (Stajniak, et al., 2008, p. 8). }\end{array}$ \\
\hline
\end{tabular}

Source: Own elaboration based on available literature.

From the point of view of the topic of the study, the three interpretations of the term transport in Table 1 relate directly to the topic of the research (Gołembska, Bendyt, Gołembski; Jacyna, Lewczuk; Stajniak). They concern issues related to the movement of people in time and space. The study focuses on one of the types of transport - railroad transport. Railroad transport is the carriage of people and cargo using the railroad infrastructure. It includes: buildings, structures, equipment together with the land occupied under them, located in the railroad area, intended for the management, service of people and things, as well as maintenance of the infrastructure manager's property necessary for this purpose (Journal of Laws 2013, item 1594, as amended). Global rail transportation has undoubtedly been impacted by the COVID-19 infectious disease, which was declared a pandemic on March 11, 2020 (Satomi, et al., April 2020). Since then, individual countries around the world have implemented numerous restrictions in the form of wearing masks, using hand sanitizers, measuring temperature, and more (Matuka, September 2020). The COVID-19 pandemic has led to large declines in the number of passengers transported by rail in Europe (Czubinski, 2020 December 1). Large declines in the number of passengers transported by rail in Europe have shaken the economic security of the various countries under consideration.

A. Nurzyńska (Nurzyńska, 2016, p. 22) interprets economic security as a certainty of survival associated with access to markets, financial resources, which guarantees stable development of its subjects. Declines in passenger numbers (Railway Market, 2021) translate into financial losses for individual companies with interests in the rail transport sector. Long lasting losses can lead to loss of liquidity and bankruptcy. An important role of governments of individual countries is to help mainly financially to overcome the observed crisis. The method of multivariate comparative analysis was used to investigate the decrease in the number of passengers transported by rail in 28 European countries. In literature the term multivariate data analysis refers to a group of statistical methods that simultaneously analyze at least two variables describing each object (Luniewska, Tarczynski, 2006, p. 9). Additionally, the data were clustered and further analyzed using metrics to capture patterns such as trend or seasonality seen in the raw data from 2012 to 2019 (Kozicki, Bryczek-Wrobel, 2020; Kozicki, Mitkow, 2020; Makridakis, Wheelwright, Hyndman, 1998). The patterns detected will also be used to interpret the declines in the number of passengers transported by rail in 28 European countries in 2020.

\section{A multivariate comparative analysis of declines in the number of passengers transported by rail}

The research began by outlining data on the total number of passengers transported by rail in 28 European countries between 2012 and 2020. 


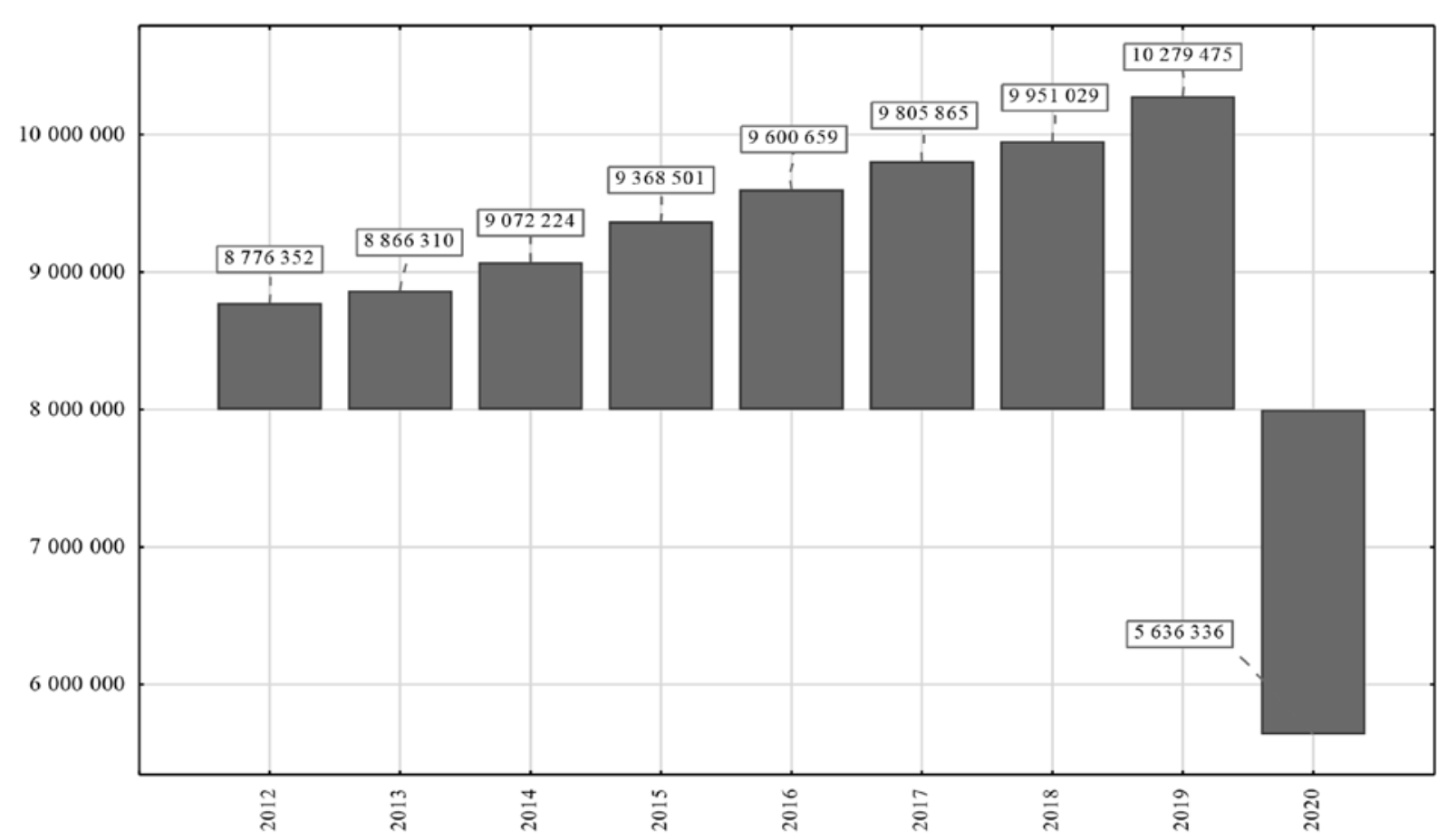

Figure 1: Bar graph of the total number of passengers transported by rail in 28 European countries in 2012-2020.

Source: own elaboration based on data from: https://ec.europa.eu/ (6.06.2021).

Observation of the data outlined in Figure 1 allows the conclusion that from 2012 to 2019 an increasing trend in the number of passengers transported by rail transport was evident in the 28 countries of Europe under consideration combined. A total of $81,356,751$ passengers were transported by rail in the 28 countries of Europe under study between 2012 and 2020. In 2012 the number of passengers transported was 8,776,352 and in 2019 it increased to 10,279,475. From 2012 to 2019 there was an increase of 17.13 p.p. in the number of passengers transported by rail. In 2020, due to the impact of the COVID-19 pandemic, decreases were observed in the number of passengers transported by rail in the 28 European countries considered in total, from 10,279,475 in 2019 to 5,636,336. The decrease in 2020 compared to 2019 was 4,643,139 passengers, or 45.17 p.p. The arithmetic mean of the number of passengers carried in the 28 European countries considered between 2012 and 2020 was 80,711.06. In 2012 it was at 78,360.29. By 2019 it was observed to increase steadily to 91,781.03, while in 2020, due to the COVID-19 pandemic, there was a decrease in the arithmetic mean to a value of $50,324.43$. The standard deviation from the arithmetic mean of the data under consideration was $162,272.4$ in 2019 and decreased to $98,971.1$ in 2020. The next step of the study was to plot a bar chart of the number of passengers transported by rail in 28 individual European countries from 2012 to 2020, along with a ranking from the highest to the lowest value in 2019 according to the number of passengers transported (Figure 2-4). 


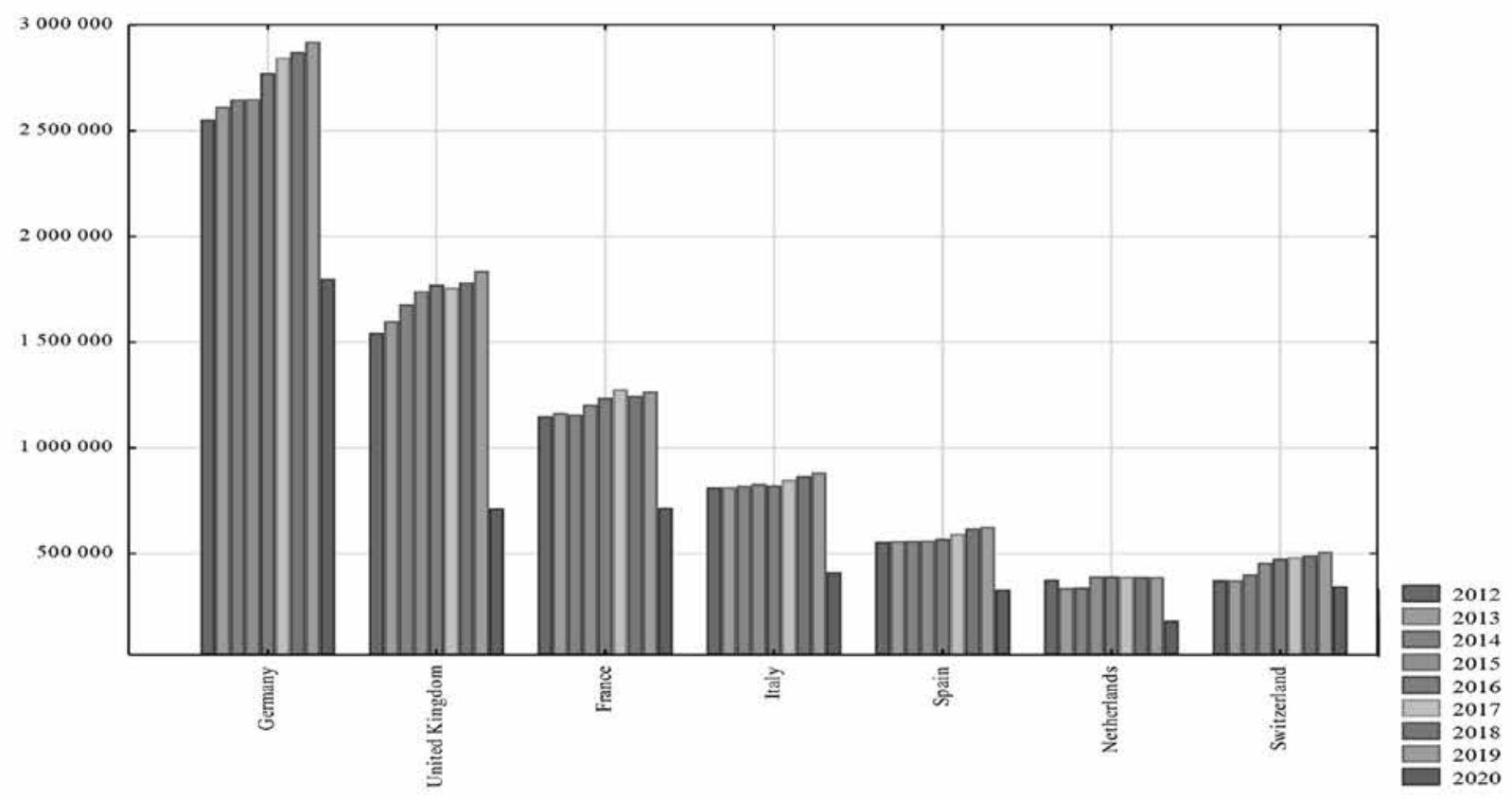

Figure 2: Bar graph of the number of passengers transported by rail in 7 of 28 of individual European countries in 2012-2020 (ranking from the highest to the lowest value in 2019 according to the number of passengers carried) (scale from 400,000 to 3,000,000)

Source: own elaboration based on data from: https://ec.europa.eu/ (6.06.2021).

The leader among the considered 28 European countries for the highest number of passengers transported by rail between 2012 and 2020 is Germany (Figure 2). In 2019, 2,921,636 passengers were transported there. The following countries are ranked next: 2nd UK; 3rd France; 4th Italy; 5th Spain; 6th Netherlands, followed by Switzerland in 7th place. Six countries out of the seven shown in Figure 2 show an increasing trend in the number of passengers transported by rail from 2012 to 2019, followed by decreases in 2020 caused by the impact of the COVID-19 pandemic. Only the Netherlands in $2013(336,683)$ and $2014(339,179)$ shows decreases in the number of passengers transported by rail compared to 2012 (375837), followed by an increase to 392,153 in 2015. 2015 to 2019 shows a similar level of passenger numbers in the Netherlands with a gentle decreasing trend to 388,984 passengers in 2019. In 2020, similar to the other European countries considered, there is a decrease in the number of passengers carried to a level of $181,541$.

Figure 3 shows the results of further ranking from highest to lowest number of passengers transported by passenger rail in the 28 considered European countries in 2019. 


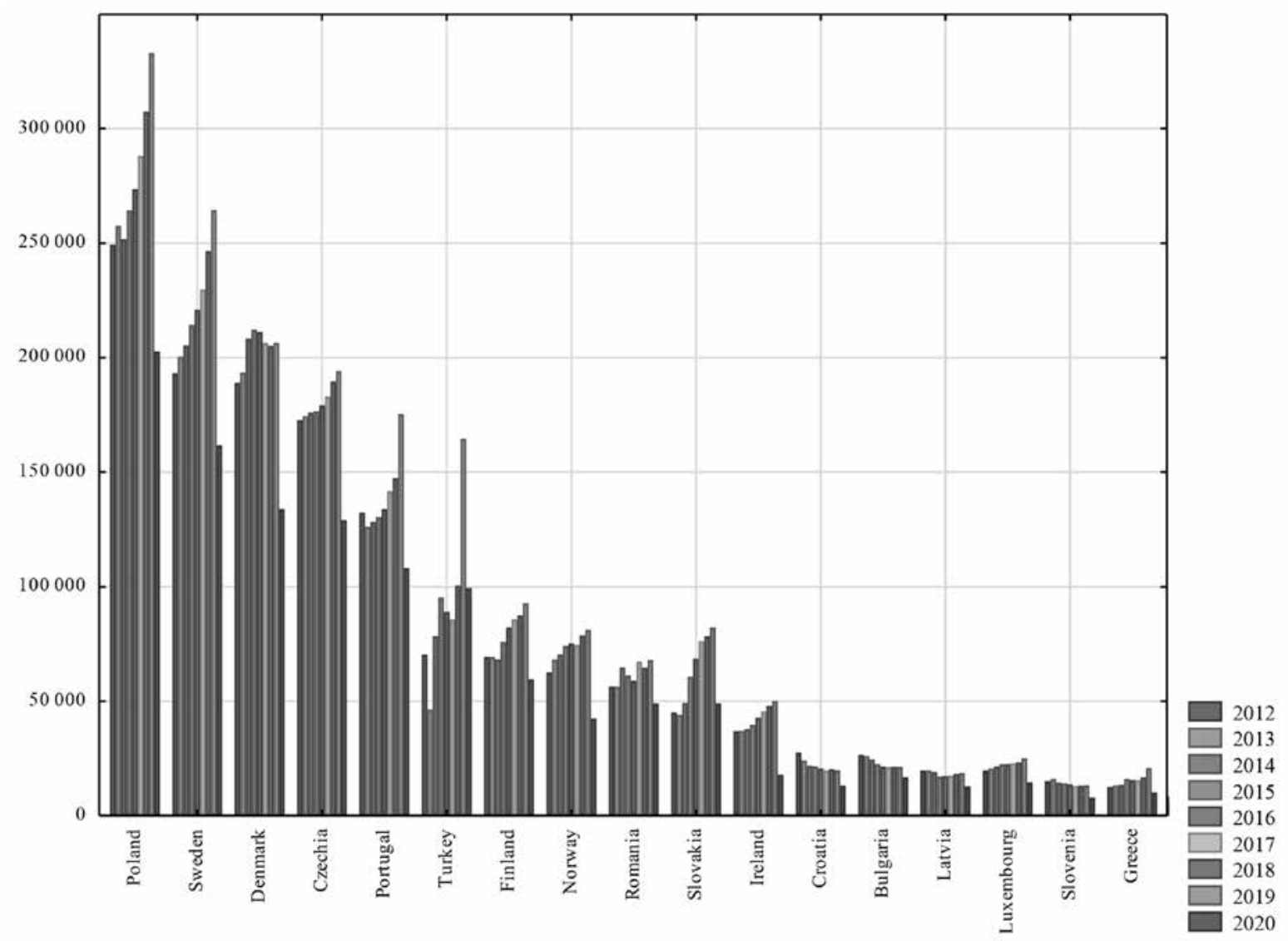

Figure 3: Bar chart of the number of passengers transported by rail in 17 out of 28 individual European countries between 2012 and 2020 (ranked from highest to lowest in 2019 by number of passengers carried) (scale from 8,000 to 400,000).

Source: own elaboration based on data obtained from: https://ec.europa.eu/; (6.06.2021).

In eighth place in the ranking of the highest number of passengers transported by rail in 28 European countries is Poland (2019 - number of passengers 332,958). The following countries occupy the next places: 9th Sweden; 10th Denmark; 11th Czech Republic; 12th Portugal; 13th Turkey; 14th Finland; 15th Norway; 16th Romania; 17th Slovakia; 18th Ireland; 19th Croatia; 20th Bulgaria; 21st Latvia; 22nd Luxembourg; 23rd Slovenia and 24th place Greece. Among the seventeen European countries shown in Figure 3, thirteen have seen an increasing trend in the number of passengers transported by rail from 2012 to 2019, while the remaining four have seen a decreasing trend. In each of the countries considered, a decrease in the number of passengers transported by rail was observed in 2020 due to the COVID-19 pandemic.

Figure 4 then shows the results of further ranking of the 28 considered European countries 


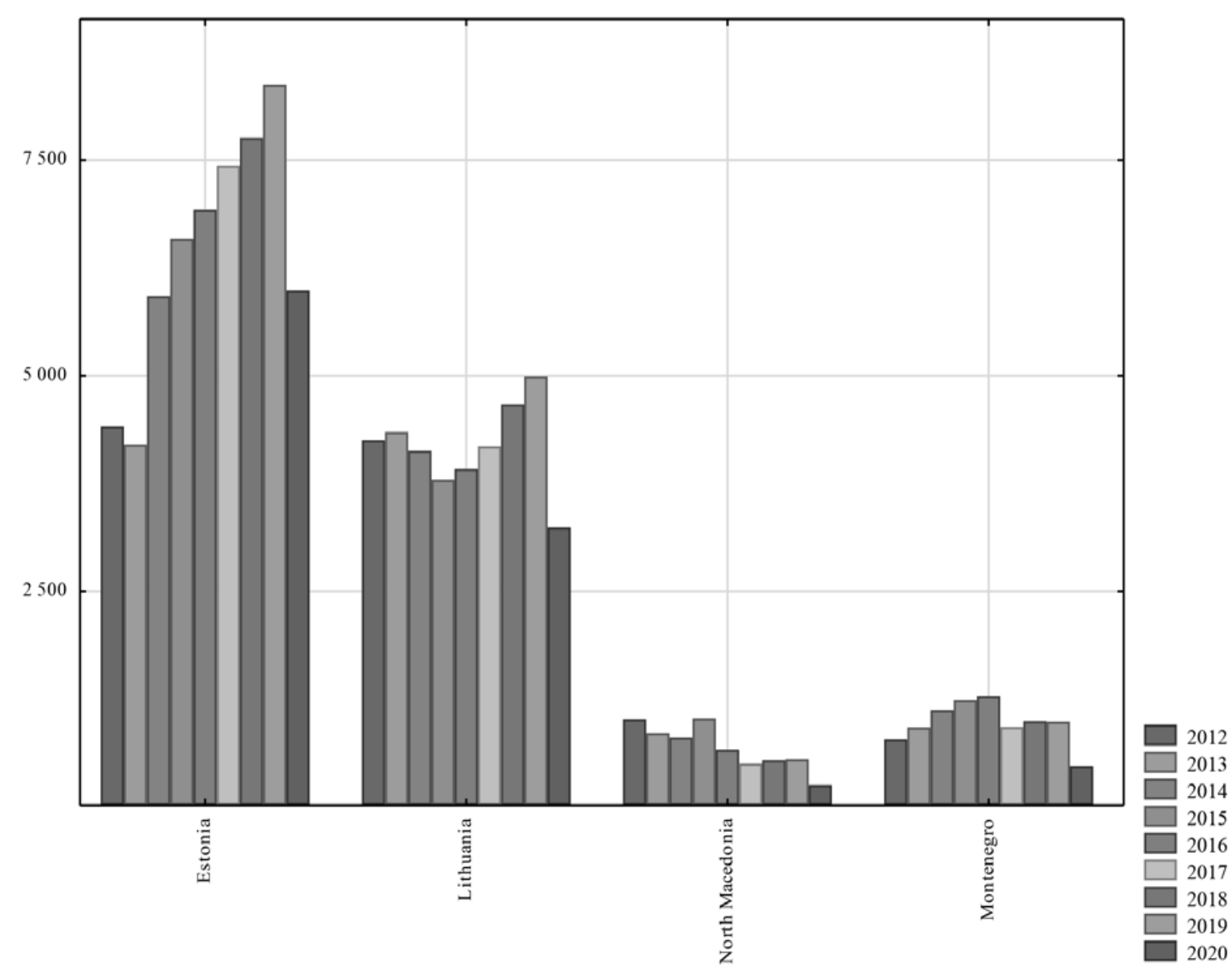

Figure 4: Bar chart of the number of passengers transported by rail in 4 out of 28 individual European countries between 2012 and 2020 (ranked from highest to lowest in 2019 by number of passengers carried) (scale from 0 to 8,000 )

Source: own elaboration based on data obtained from: https://ec.europa.eu/; (6.06.2021)

According to the evaluation of Figures 2-4, the twenty-fifth place in the ranking is Estonia. The following countries are ranked next: 26th Lithuania; 27th North Macedonia and 28th Montenegro. Three of the four countries in Figure 4 showed an upward trend from 2012 to 2019, which alternated in some years (2015-2018) (both increases and decreases occurred). Figure 4 shows only one decreasing trend from 2012 (1012 passengers) to 2019 (549 passengers) in North Macedonia (the only increase in 2015 to 1022 passengers). Similar to Figures 2-3, decreases in the number of passengers transported by rail caused by the COVID-19 pandemic were observed in the countries shown in Figure 4.

The next step of the research was to analyze the dynamics of changes in the number of passengers transported by rail in 28 individual European countries between 2012 and 2020 (Figure 5). 


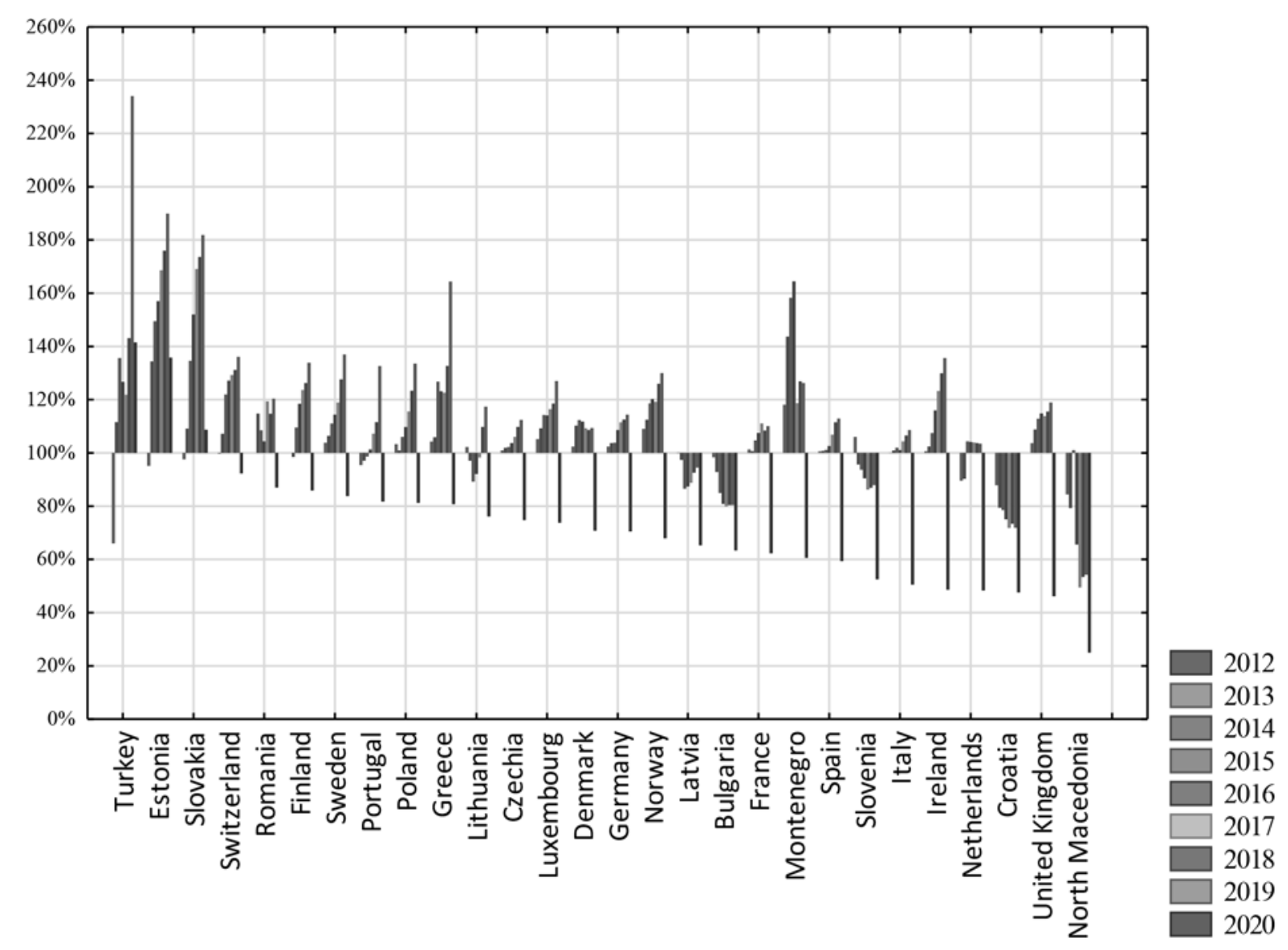

Figure 5: Bar chart of the dynamics indicators with a constant base of the number of passengers transported by rail in 28 European countries in 2012-2020 (constant value - the number of passengers transported by rail in each 28 European countries in 2012) (ranked from the highest to the lowest number of passengers transported by rail in each 28 European countries in 2020)

Source: own compilation based on data from https://ec.europa.eu/; (6.06.2021)

The ranking of the dynamics of changes in the number of passengers transported by rail in 28 European countries in 2020 from the highest to the lowest value is as follows: 1 st place Turkey $-141.52 \%$; followed by 2 nd place Estonia - 135.75\%; 3rd place Slovakia - 108.70\%; 4th place Switzerland - 92.26\%; 5th place Romania $87.01 \%$; 6th place Finland - 85.89\%; 7th place Sweden - 83.76\%; 8th place Portugal - 81.72\%; 9th place Poland $-81.27 \%$; 10th place Greece - 80.74\%; 11 th place Lithuania - 76.15\%; 1st place Czechia - 74.73\%; 13th place Luxembourg - 73.78\%; 14th place Denmark - 70.85\%; 15th place Germany - 70.52\%; 16th place Norway $-67.93 \%$; 17 th place Norway $-67.93 \%$. Germany - 70,52\%; 16. Norway - 67,93\%; 17. Latvia - 65,27\%; 18. Bulgaria - 63,32\%; 19. France - 62,29\%; 20. Montenegro - 60,56\%; 21. Spain - 59,33\%; 22. Slovenia $52,53 \% ; 23$. Italy - 50,53\%; 24. Ireland - 48,57\%; 25. Netherlands - 48,30\%; 26. Croatia - 47,61\%; 27. United Kingdom - 46,17\%; 28. North Macedonia - 25,00\%. In four of the 28 countries considered, a clear downward dynamic in the number of passengers transported by rail is evident from 2012 to 2019 (in all years). These are: Latvia, Bulgaria, Croatia and North Macedonia. An increasing trend from 2012 to 2019 with few decreases was observed in 23 European countries out of 28 considered (ranking from highest to lowest dynamics from 2012 to 2019 with constant base - constant year 2012): 1. Turkey - 134.02\%; 2. Estonia - 89.88\%; 3. Slovakia - 81.87\%; 4. Greece - 64.37\%; 5. Sweden - 36.98\%; 6. Switzerland - 36.10\%; 7. Ireland - 35.60\%; 8. Finland - 33.85\%; 9. Poland - 33.50\%; 10. Portugal - 32.61\%; 11. Norway - 29.97\%; 12. Luxembourg - 27.04\%; 13. Montenegro - 26,25\%; 14. Romania - 20,37\%; 15. United Kingdom - 18,97\%; 16. Lithuania - 17,41\%; 17. Germany 14,39\%; 18. Spain - 12,92\%; 19. Czech Republic - 12,39\%; 20. France - 10,08\%; 2. Denmark - 9,31\%; 22. Italy $-8,57 \% ; 23$. Netherlands $-3,50 \%$. The lowest dynamics in the transport of passengers by rail in the 28 European countries under consideration was recorded in five countries (ranking from the highest to the lowest dynamics in 2012-2019 with constant basis - constant year 2012): 24th Latvia - (-5.51\%); 25th Slovenia - 
(-12.10\%); 2nd Bulgaria - (-19.54\%); 27th Croatia - (-28.10\%); 28th North Macedonia - (-45.75\%). The next stage of the research was the analysis of the difference in the number of passengers transported by rail between 2019 and 2020 in 28 individual European countries (Figure 6).

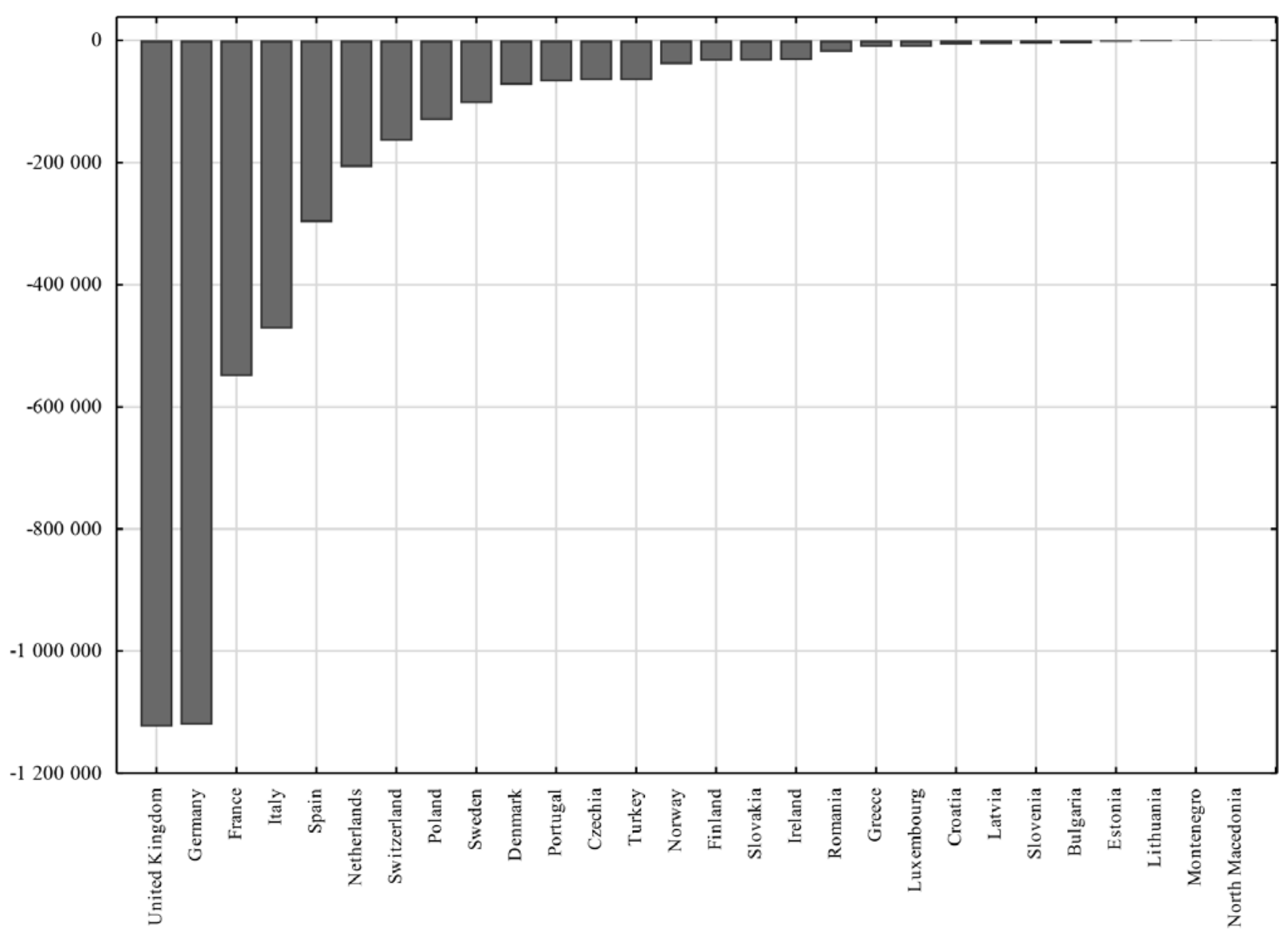

Figure 6: Bar chart of the difference in the number of passengers carried between 2019 and 2020 in 28 individual European countries (ranking from lowest to highest value)

Source: own elaboration based on data obtained from the website: https://ec.europa.eu/; (6.06.2021)

A ranking of the decreases in the number of passengers transported by rail due to the COVID-19 pandemic in 28 individual European countries between 2019 and 2020 is as follows (from highest absolute value to lowest): 1. United Kingdom - 1123999; 2. Germany - 1120519; 3. France - 549738; 4. Italy - 472205; 5. Spain - 297629; 6. Netherlands - 207443; 7. Switzerland - 164057; 8. Poland - 130270; 9. Sweden - 102814; 10. Denmark 72700; 11. Portugal - 67294; 12. Czech Republic - 65067; 13. Turkey - 65015; 14. Norway - 38806; 15. Finland - 33252; 16. Slovakia - 33019; 17. Ireland - 32130; 18. Romania - 18822; 19. Greece - 10584; 20. Luxembourg - 10487; 21. Croatia - 6698; 22. Latvia - 5760; 23. Slovenia - 5336; 24. Bulgaria - 4545; 25. Estonia - 2387; 26. Lithuania - 1754; 27. Montenegro - 513; 28. North Macedonia - 296. The next stage of the research was to compile the percentage decreases in the number of passengers carried in 2020 compared to 2019 in the 28 considered European countries. 


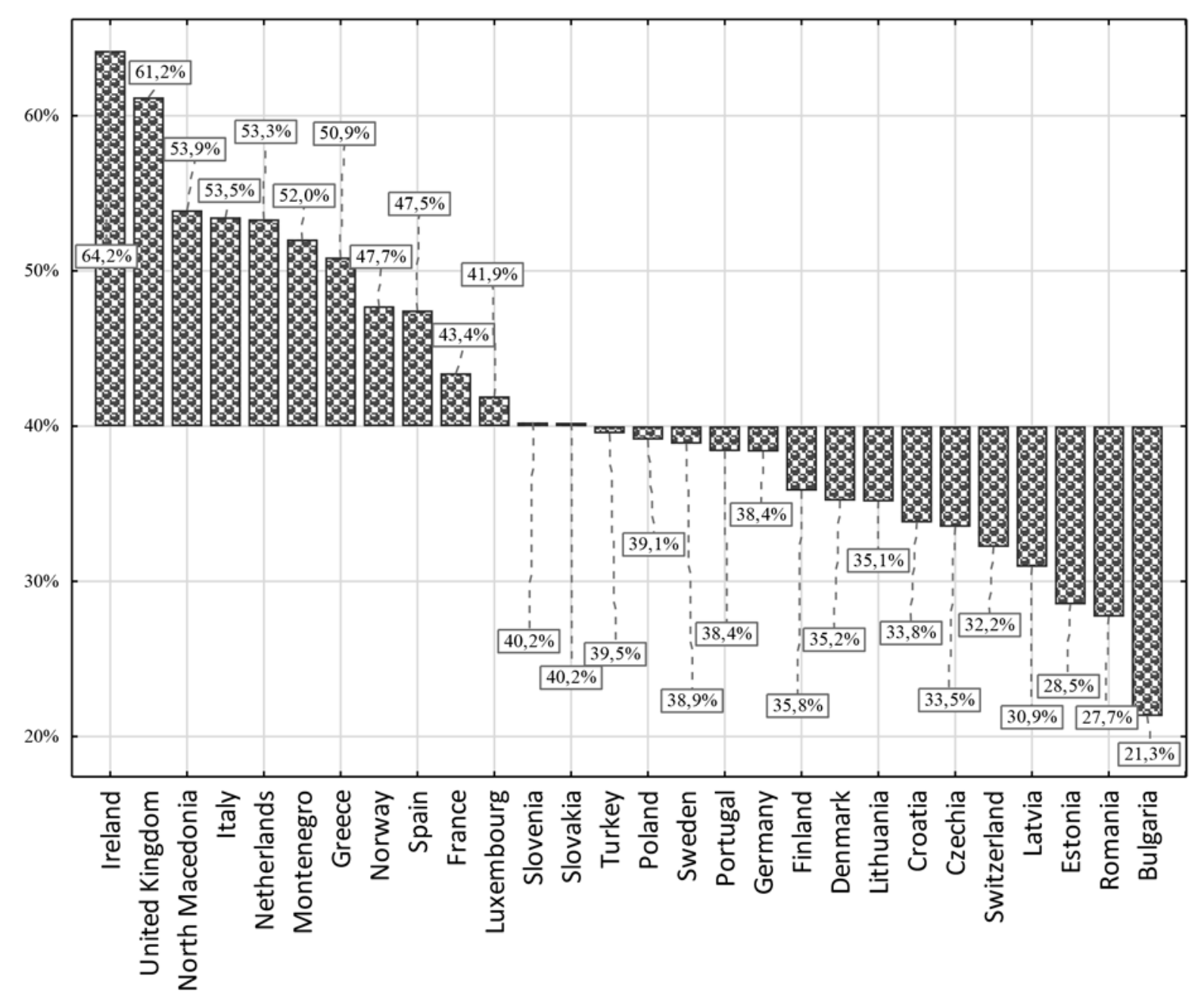

Figure 7: Bar chart of the \% decrease in the number of passengers carried in 2020 compared to 2019 in 28 individual European countries (ranking from the highest to the lowest value).

Source: own elaboration based on data from: https://ec.europa.eu/; (6.06.2021).

The ranking of the \% decrease in the number of passengers carried in 2020 compared to 2019 in the 28 individual European countries from the highest to the lowest value carried out in Figure 7 is as follows: 1. Ireland - 64.18\%; 2. United Kingdom - 61.19\%; 3. North Macedonia - 53.92\%; 4. Italy - 53.46\%; 5. Netherlands $53.33 \%$; 6. Montenegro - 52.03\%; 7. Greece - 50.88\%; 8. Norway - 47,73\%; 9. Spain - 47,46\%; 10. France 43,41\%; 11. Luxembourg - 41,92\%; 12. Slovenia - 40,24\%; 13. Slovakia - 40,23\%; 14. Turkey - 39,53\%; 15. Poland - 39,13\%; 16. Sweden - 38,86\%; 17. Portugal - 38,38\%; 18. Germany - 38,35\%; 19. Finland - 35,83\%; 20. Denmark - 35,19\%; 21. Lithuania - 35,14\%; 22. Croatia - 33,78\%; 23. Czech Republic - 33,50\%; 24. Switzerland - 32,22\%; 25. Latvia - 30,93\%; 26. Estonia - 28,51\%; 27. Romania - 27,72\%; 28. Bulgaria - 21,31\%. The next step of the research was to analyze the sum of the number of passengers transported by rail in the 28 European countries combined in quarters in the respective years 2012-2020 (Figure 8). 


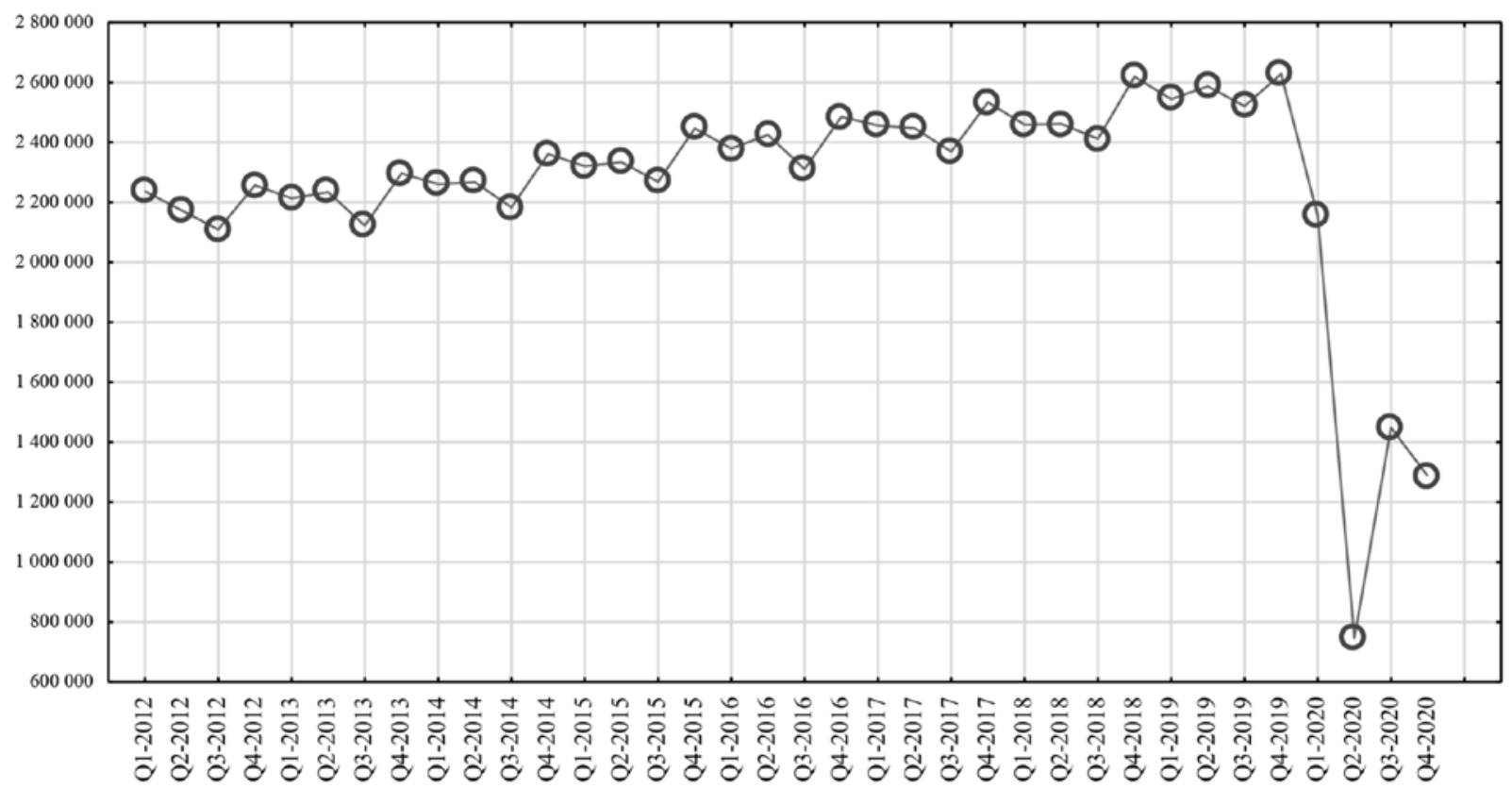

Figure 8: Line graph of the sum of the number of passengers transported by rail in the 28 countries of Europe in total in the quarters of 2012-2020.

Source: own elaboration based on data from: https://ec.europa.eu/; (6.06.2021)

Observation of the data in Figure 8 allows the conclusion that from Q1 2012 to Q4 2019 a trend of an increasing nature and quarterly seasonality was evident. From Q1 to Q4 2020, large decreases in the number of passengers transported by rail are visible in a total of 28 European countries. The lowest level of passengers transported by rail in the 28 European countries was recorded in Q2 2020. At that time, a total of 746,455 people were transported in the 28 countries of Europe. It should be emphasized that the decrease from Q4 2019, where the number of passengers transported was 2,628,126, occurred by 1,881,671 passengers. In the 3rd quarter of 2020, an increase in the number of passengers carried was observed to $1,448,094$, while in the following quarter the decrease was observed to $1,287,142$. The two decreases observed in the 2 nd and 4th quarters of 2020 are due to the introduction of restrictions by individual European countries associated with an increase in the incidence of diseases caused by the COVID-19 infectious disease pandemic. Increases in the incidence of diseases are commonly referred to as the emergence of so-called waves of disease. Considering the data on the number of people transported by rail in 28 European countries together in the same quarters from 2012 to 2019, it can be observed that the arithmetic average of the considered data clearly indicates the phenomenon of seasonality. The arithmetic mean of the first quarter was $84,240.93$ passengers. In the second quarter, it increased slightly to $84,502.50$ passengers. In the third quarter, however, it decreased to 81672.61 passengers, while in the fourth quarter it increased to 87621.53 passengers.

The total arithmetic mean of the primary data considered for the univariate quarters from 2012 to 2020 was $84,509.39$ passengers. For the univariate data on a quarterly basis in 2020 through the impact of the COVID-19 pandemic, the pattern of quarterly seasonality in the first and second quarters evident in the retrospective data (2012-2019) was not maintained. In the first quarter of 2020, the arithmetic mean was 76,951.61 passengers. In the second quarter a large decrease was observed to the level of 26659,11 . The regularity in the form of seasonality can be found in the third and fourth quarter of 2020. At the same time, this may be a misinterpretation, because the primary data in the form of number of passengers transported by rail were affected by typical random factors in the form of restrictions introduced by individual European countries in connection with the increase of infections caused by the infectious disease COVID-19 in 2020.

It should be emphasized that in the third quarter of 2020 there was an increase in the number of passengers transported by rail in the considered countries of Europe in total to 51717.64 passengers, while in the fourth 
quarter there was a decrease to the level of 13359.50 passengers. The next step of the research is to analyze the declines in the number of passengers carried in the univariate quarters between 2019 and 2020 in the 28 individual European countries considered. The results of the study are summarized in Figures 9-11, ranking them from largest to smallest declines in the unipolar second quarter between 2019 and 2020.

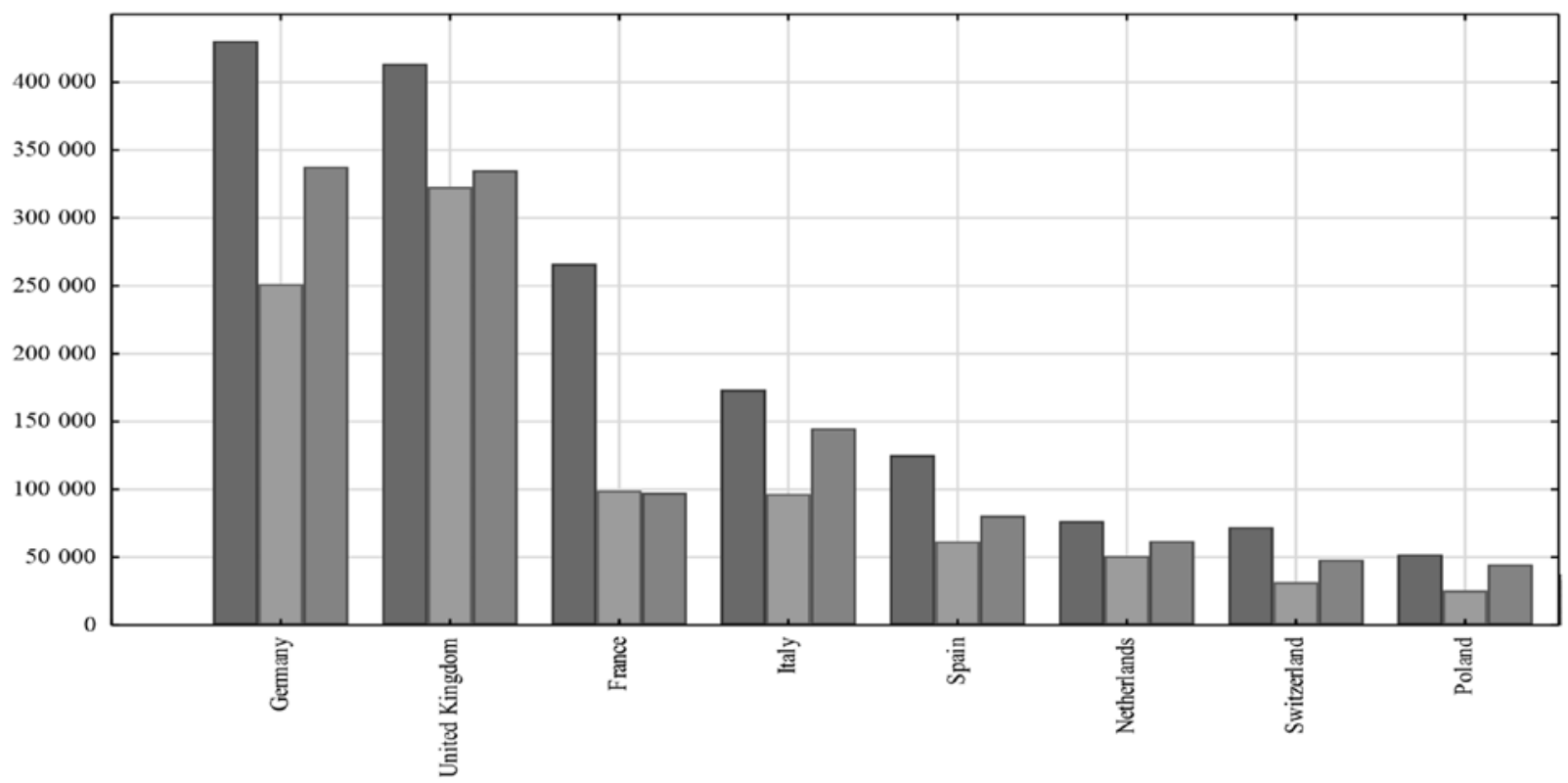

Q2 2019 - Q2 2020

Q3 2019 - Q3 2020

Q4 2019 - Q4 2020

Figure 9: Bar chart of the difference in the number of passengers carried in univariate quarters (Q2, Q3, Q4) between 2019 and 2020 in 8 of the 28 European countries (ranking from highest to lowest value according to the difference in univariate Q2 quarters between 2019 and 2020) (scale from 40,000 to 450,000).

Source: own compilation based on data extracted from: https://ec.europa.eu/; (6.06.2021).

The highest declines in rail passengers caused by the COVID-19 pandemic in the single two quarters between 2019 and 2020 were recorded in Germany, which saw a reduction of 430,410 passengers. In second place is the United Kingdom with a decrease of 413,550 passengers. France is third with 266,217, followed by: 4th Italy 173 444; 5th Spain - 125 300; 6th Netherlands -76 697; 7th Switzerland - 72 231; 8th Poland - 52 043. Observation of the data in Figure 9 allows us to formulate a conclusion that in case of 7 out of 8 presented countries in the fourth quarter we can see an increase in decreases in comparison to the third quarter caused by the so-called increase of the wave of diseases and further restrictions from individual considered countries related to, among others, rules of movement. 


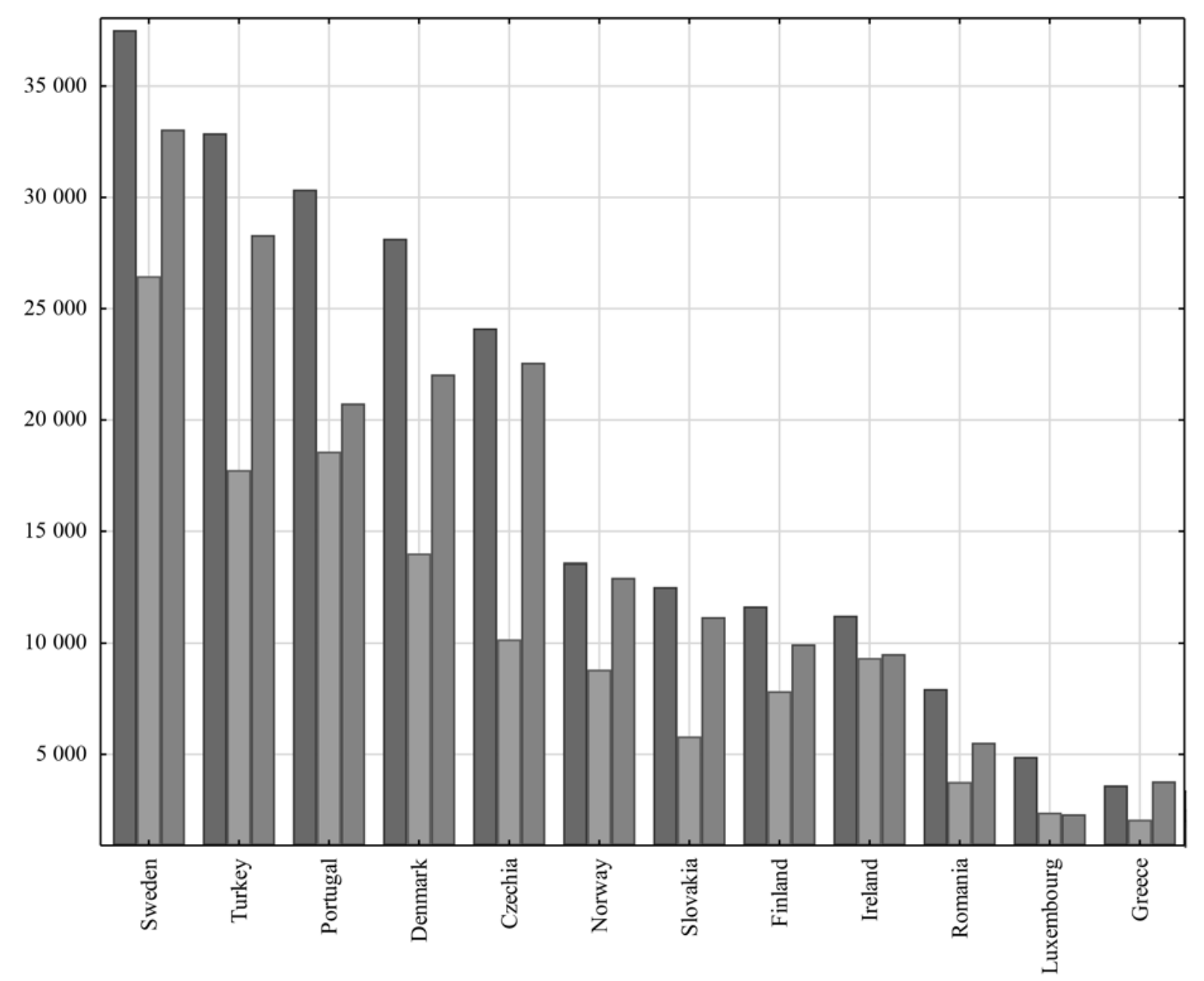

Q2 2019 - Q2 2020

Q3 2019 - Q3 2020

Q4 2019 - Q4 2020

Figure 10: Bar chart of the difference in the number of passengers carried in univariate quarters (Q2, Q3, Q4) between 2019 and 2020 in 12 of the 28 European countries (ranking from highest to lowest value according to the difference in univariate Q2 quarters between 2019 and 2020) (scale from 3,500 to 40,000)

Source: own compilation based on data extracted from: https://ec.europa.eu/; (6.06.2021)

A continuation of the ranking outlined in Figure 9 is shown in Figure 10. The following countries are ranked next: 9 . Sweden - 37,522; 10. Turkey - 32,884; 11. Portugal - 30,355; 12. Denmark - 28,149; 13. Czechia 24,$117 ; 14$. Norway - 13,597; 15. Slovakia - 1,519; 16. Finland - 11,649; 17. Ireland - 11,232; 18. Romania 7,943; 19. Luxembourg - 4,893; 20. Greece - 3,606. Similar to the data outlined in Figure 9, the data in Figure 10 shows an increase in the declines in rail passengers carried in the fourth quarter compared to the third quarter of 2020 in 11 of the 12 European countries considered. Declines in the fourth quarter $(2,381)$ lower than in the third quarter $(2,381)$ were only observed in Luxembourg. 


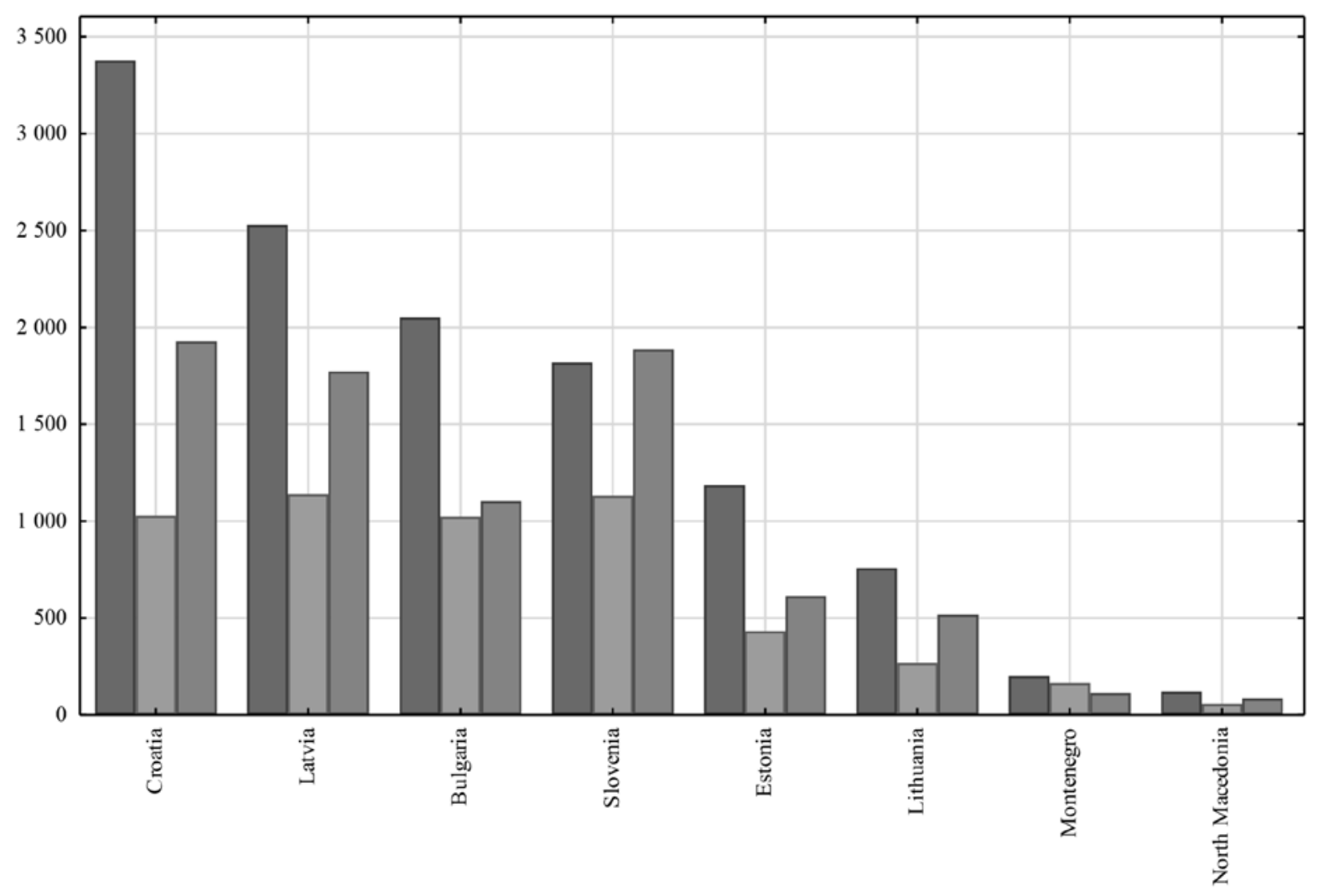

Q2 2019 - Q2 2020

Q3 2019- Q3 2020

Q4 2019- Q4 2020

Figure 11: Bar chart of the difference in the number of passengers carried in univariate quarters (Q2, Q3, Q4) between 2019 and 2020 in 8 of the 28 European countries (ranking from highest to lowest value according to the difference in univariate Q2 quarters between 2019 and 2020) (scale from 0 to 3,500)

Source: own compilation based on data extracted from: https://ec.europa.eu/; (6.06.2021)

A continuation of the ranking outlined in Figures 9 and 10 is shown in Figure 11. The following countries are ranked next: 21. Croatia - 3,378; 22. Latvia - 2,528; 23. Bulgaria - 2,051; 24. Slovenia - 1,820; 25. Estonia 1,185; 26. Lithuania - 757; 27. Montenegro - 199; 28. North Macedonia - 119.

Seven out of the eight European countries considered (Figure 11) show an increase in declines in the number of passengers transported by rail in the fourth quarter compared to the third quarter of 2020. Only Montenegro shows a larger decrease in the third quarter compared to the fourth quarter.

\section{Summary and conclusions}

The study shows that the COVID-19 pandemic has led to large declines in the number of passengers transported by rail in Europe. The largest decreases in 2020 compared to 2019 were recorded in the following countries: 1. United Kingdom - 1123999; 2. Germany - 1120519; 3. France - 549738; 4. Italy - 472205; 5. Spain - 297629; 6. Netherlands - 207443; 7. Switzerland - 164057; 8. Poland - 130270; 9. Sweden - 102814; 10. Denmark - 72700; 11. Portugal - 67294; 12. Czechia - 65067; 13. Turkey - 65015; 14. Norway - 38806; 15. Finland - 33252; 16. Slovakia - 33019; 17. Ireland - 32130; 18. Romania - 18822; 19. Greece - 10584; 20. Luxembourg - 10487; 21. Croatia - 6698; 22. Latvia - 5760; 23. Slovenia - 5336; 24. Bulgaria - 4545; 25. Estonia - 2387; 26. Lithuania $1754 ; 27$. Montenegro - 513; 28. North Macedonia - 296. The aim of the study has been achieved.

The decrease in 2020 in the 28 European countries under consideration compared to 2019 occurred by 4,643,139 
passengers or 45.17 p.p. When considering the ranking of the \% decrease in the number of passengers carried in 2020 compared to 2019 in the 28 individual European countries from the highest value to the lowest value, the individual European countries under consideration were ranked as follows: 1. Ireland - $64.18 \%$; . United Kingdom - 61.19\%; 3. North Macedonia - 53.92\%; 4. Italy - 53.46\%; 5. Netherlands - 53.33\%; 6. Montenegro $52.03 \%$; 7. Greece - 50.88\%; 8. Norway - 47,73\%; 9. Spain - 47,46\%; 10. France - 43,41\%; 11. Luxembourg 41,92\%; 12. Slovenia - 40,24\%; 13. Slovakia - 40,23\%; 14. Turkey - 39,53\%; 15. Poland - 39,13\%; 16. Sweden - 38,86\%; 17. Portugal - 38,38\%; 18. Germany - 38,35\%; 19. Finland - 35,83\%; 20. Denmark - 35,19\%; 21. Lithuania - 35,14\%; 22. Croatia - 33,78\%; 23. Czech Republic - 33,50\%; 24. Switzerland - 32,22\%; 25. Latvia - 30,93\%; 26. Estonia - 28,51\%; 27. Romania - 27,72\%; 28. Bulgaria - 21,31\%. Thus, the research hypothesis posed at the beginning of the study has been verified.

In the study, a lot of valuable information was obtained as a basis for choosing the method of forecasting the considered primary data for the future. Namely, the trend and seasonality were observed on a quarterly basis. In four of the 28 countries considered, a clear (in all years) downward dynamics in the number of passengers transported by rail is visible from 2012 to 2019. These are: Latvia, Bulgaria, Croatia and North Macedonia.

An increasing trend from 2012 to 2019 with few decreases was observed in 23 out of 28 European countries considered (ranking from highest to lowest dynamics from 2012 to 2019 with a constant base - constant year 2012): 1. Turkey - 134.02\%; 2. Estonia - 89.88\%; 3. Slovakia - 81.87\%; 4. Greece - 64.37\%; 5. Sweden $36.98 \%$; 6. Switzerland - 36.10\%; 7. Ireland - 35.60\%; 8. Finland - 33.85\%; 9. Poland - $33.50 \%$; 10 . Portugal $32.61 \%$; 11. Norway - 29.97\%; 12. Luxembourg - 27.04\%; 13. Montenegro - 26,25\%; 14. Romania - 20,37\%; 15. United Kingdom - 18,97\%; 16. Lithuania - 17,41\%; 17. Germany - 14,39\%; 18. Spain - 12,92\%; 19. Czech Republic - 12,39\%; 20. France - 10,08\%; 21. Denmark - 9,31\%; 22. Italy - 8,57\%; 23. Netherlands - 3,50\%.

Declines in the number of passengers carried by passenger rail transport are so large and have already persisted since February 2020 that they require financial support from the European Union, as well as from national governments in the form of adequate financial outlays to cover the fixed costs that are still being incurred, as well as a precise EU reconstruction programme and international agreements to support the rail transport sector in Europe.

\section{References:}

Czubiński R., Great drops in passenger transport in Europe. The Netherlands is an exception (Wielkie spadki przewozów pasażerskich w Europie. Holandia wyjątkiem), Eurostat, https://www.rynekkolejowy.pl/mobile/eurostat-wielkie-spadki-przewozow-pasazerskich-w-europie-holandia-wyjatkiem $99796 . \mathrm{html}$

Gołembska E., Bentyn Z., Gołembski M., Logistics of services. Current development trends. Latest research results. Proven management methods (Logistyka usług. Aktualne trendy rozwoju. Najnowsze wyniki badań. Sprawdzone metody zarządzania), Warsaw 2017. Jacyna M., Lewczuk, K., Designing logistic systems (Projektowanie systemów logistycznych), Warsaw 2016.

Jurgilewicz M et al., The implementation of selective passenger screening systems based on data analysis and behavioral profiling in the smart aviation security management - conditions, consequences and controversies, Journal of Security and Sustainability Issues 9(4), June 2020, 1145-1155.

Karbowiak H., Fundamentals of transport infrastructure (Podstawy infrastruktury transportu), Łódź 2009.

Kozicki B., Bryczek-Wróbel P., The Impact of Covid-19 Pandemic on Energy Security by Demand Analysis for Oil and Air Passengers in European Countries, European Research Studies Journal, vol. XXIII, Special Issue 3, 201-212, 2020. https://doi.org/10.35808/ ersj/1862

Kozicki B., Mitkow Sz., Analysis of Human Deaths in Regard to Covid-19 Pandemic in European Countries, European Research Studies Journal, vol. XXIII, Special Issue 3, s. 213-227, 2020. https://doi.org/10.35808/ersj/1878

Łuniewska M., Tarczyński W., Methods of multidimensional comparative analysis on the capital market (Metody wielowymiarowej analizy porównawczej na rynku kapitałowym), Warsaw 2006.

Makridakis S.G., Wheelwright S.C., Hyndman R.J., Forecasting methods and applications, New York 1998. 
Matuka A. (September 2020). COVID-19 Outbreak and US Economic Policy Uncertainty: An ARDL Approach, SSRN Electronic Journal, https://www.researchgate.net/publication/344083397

Nurzyńska A., Security of services in international passenger air transport (Bezpieczeństwo usług w międzynarodowym transporcie lotniczym przewozów pasażerskich), Katowice 2016.

Rynek kolejowy (14.01.2021), UTK estimates the decrease in the number of passengers in 2020 at $40 \%$ (UTK szacuje spadek liczby pasażerów w 2020 r. na 40\%), https://www.rynek-kolejowy.pl/wiadomosci/monitorowanie-bezpieczenstwa-w-czasie-epidemii-100456. $\mathrm{html}$

Satomi E., et al. (April 2020), Alocação justa de recuros de saúde escassos diante da pandemia de COVID-19 Considerações éticas, Einstein, São Paulo 18(2):1-5, https://doi.org/10.31744/einstein journal/2020AE5775

Stajniak M., Hajdul M., Foltyński M., Krupa A., Transport and shipping (Transport i spedycja), Instytut Logistyki i Magazynowania, Poznań 2008.

Superna B., Rail passenger transport decreased by 37.7\%, and freight by 5.6\% in 2020 (Przewozy pasażerskie na kolei spadły o 37,7\%, towarowe o 5,6\% w 2020), https://inwestycje.pl/biznes/przewozy-pasazerskie-na-kolei-spadly-o-377-towarowe-o-56-w-2020/

Marek Magniszewski, Rzeszów University of Technology, PL. Research interests: international security, international relations. ORCID ID: 0000-0002-9088-8159

Bartosz Kozicki, Military University of Technology, PL. Research interests: national security, internal security.

ORCID ID: 0000-0001-6089-952X

This work is licensed under the Creative Commons Attribution International License (CC BY). http://creativecommons.org/licenses/by/4.0/ 